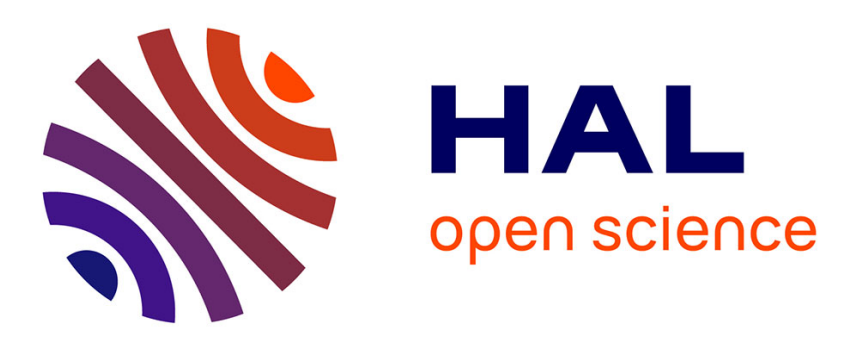

\title{
Histological study of a dcpd-based calcium phosphate cement
}

Patrick Frayssinet, L. Gineste, P. Conte, Jacques Fages, Nicole Rouquet, A.

Lerch

\section{To cite this version:}

Patrick Frayssinet, L. Gineste, P. Conte, Jacques Fages, Nicole Rouquet, et al.. Histological study of a dcpd-based calcium phosphate cement. L. Sedel, C. Rey. Bioceramics, 10, Pergamon, pp.493-496, 1997, Bioceramics, 9780080426921. hal-01846947

\section{HAL Id: hal-01846947 \\ https://hal.science/hal-01846947}

Submitted on 24 Aug 2018

HAL is a multi-disciplinary open access archive for the deposit and dissemination of scientific research documents, whether they are published or not. The documents may come from teaching and research institutions in France or abroad, or from public or private research centers.
L'archive ouverte pluridisciplinaire HAL, est destinée au dépôt et à la diffusion de documents scientifiques de niveau recherche, publiés ou non, émanant des établissements d'enseignement et de recherche français ou étrangers, des laboratoires publics ou privés. 


\title{
HISTOLOGICAL STUDY OF A DCPD-BASED CALCIUM PHOSPHATE CEMENT.
}

\author{
Patrick Frayssinet* ${ }^{\circ}$, Laurent Gineste ${ }^{\#}$, Philippe Conte**, Jacques Fages*, Nicole Rouquet*, Alain \\ Lerch*
}

* $\quad$ Bioland, 132 route d'Espagne, 31100 Toulouse, France

** Service de Chirurgie Orthopédique, CHU Toulouse Purpan, Toulouse, France

- Laboratoire du Tissu Osseux et des Pathologies Ostéoarticulaires, Université Paul

Sabatier, Toulouse, France.

\# Service de Biologie Buccale. Ecole Dentaire, Université Paul Sabatier, 31400 Toulouse

\begin{abstract}
A DCPD based calcium phosphate cement has been implanted and set within rabbit condyles. Histological sections were performed at 2, 6 and 18 weeks. After a mild foreign body reaction characterized by the presence of mononuclear cells at the implant surface, woven bone trabeculae formed from the cavity edges onto the material. The implant was fragmented in the early time of implantation and the fragments were invaded by cells before to be integrated within the newly formed bone matrix. At 18 weeks, the fragments had migrated in the whole condyle and the most of them were integrated while the implant volume had decreased. In conclusions: this calcium phosphate cement is a fast degradable material that can sustain bone apposition.
\end{abstract}

\section{INTRODUCTION}

Self-setting calcium phosphate cements are materials that can be handled by the surgeon in paste form and injected into bone cavities or defects. They then set to form a mineral matrix at the contact of which healing bone tissue can form. Replacement of the mineral by bone is supposed to occur as a result of the same process taking place at the calcium phosphate ceramic contact. We have developed a new calcium phosphate hydraulic cement that can set in a wet environment and be injected with a syringe into a bone defect or fracture site. The cement consists of a solid phase containing $\beta$-tricalcium phosphate and sodium pyrophosphate and a liquid phase composed of orthophosphoric and sulfuric acid. The setting reaction can be summarized as follows: $\mathrm{Ca}_{3}\left(\mathrm{PO}_{4}\right)_{2}+\mathrm{H}_{3} \mathrm{PO}_{4}+6 \mathrm{H}_{2} \mathrm{O} \rightarrow 3 \mathrm{CaHPO}_{4}, 2 \mathrm{H}_{2} \mathrm{O}$. The physico-chemical properties of the cement can be modified by the purity and the granulometry of the tricalcium phosphate. Dicalcium phosphate is known to be one of the most soluble of calcium phosphate phases (1) and can be useful when material degradable within a few weeks is needed. The aim of the described experiment was to check that the material set when injected by syringe into a bone cavity, and to examine the short term effects of the material on the surrounding tissues.

\section{MATERIALS AND METHODS}

Animals :

The animals used for experiments were 9 female New Zealand white rabbits aged 6-7 months with body weights of $3700-5100 \mathrm{~g}$ and which had free access to food and water. The animals were observed daily for one week after implantation and three times a week for the remaining implantation period. The skin in the implanted region, animal mobility and behavior were noted. 


\section{Material injected:}

Powder : $3 \mathrm{~g}$ ( $\beta$-TCP : $2.954 \mathrm{~g}$, anhydrous sodium pyrophosphate: $0.046 \mathrm{~g}$ )

Liquid : $1.8 \mathrm{ml}$ (phosphoric acid ( $4 \mathrm{M})$ and sulfuric acid (0.1 M) solution).

In this study, the powder/liquid ratio was 1.3 and the conversion rate $95 \%$. The resulting solid material consisted of $95 \%$ of dihydrated dicalcium phosphate, $4 \%$ of $\beta$-tricalcium phosphate, and $1 \%$ of various mineral phases (sodium based and calcium sulfate). The density was 1.43 , the porosity $45 \%$ and the mean pore diameter $7.1 \mu \mathrm{m}$.

\section{Injection of bone cement :}

The cement was inserted under anaesthesia with intramuscular ketamine, through a lateral longitudinal skin incision over the knee, in holes drilled in the external condyles of rabbits. Holes were drilled in the external condyles of the right and left legs. The left hole was filled with the cement and the right hole was left empty as control.

Each hole was $4 \mathrm{~mm}$ in diameter and $5 \mathrm{~mm}$ in length. The cement was injected through a syringe in paste form.

3 animals were sacrified by nembutal injection after 2 weeks, 6 weeks and 18 weeks and the distal extremities of the femurs were collected.

\section{Histological processing :}

The samples were fixed in a $4 \%$ formaldehyde solution for $48 \mathrm{~h}$, dehydrated in increasing ethanol solution then embedded in PMMA (polymethylmethacrylate). Sections $5 \mu \mathrm{m}$ thick were obtained by a hard tissue microtome (Reichert-Jung Type E). They were then stained with Giemsa solution and by Von Kossa method. The remaining histological blocks were gold palladium-coated and observed by SEM under a back-scattered mode operated at $10 \mathrm{Kv}$.

\section{RESULTS}

-After two weeks: the implantation zone was occupied by a solid cylinder made of mineral grains that had been partly removed from the section by the microtome blade. Thin newly-formed trabeculae originating from the cortical zone were inserted perpendicularly to the implant surface. These trabeculae were surrounded by an osteoid layer lined with active osteoblasts. Bone marrow cavities between these trabeculae were filled with connective tissue containing many fibroblast-like cells and bone trabeculae fragments. No hematopoietic cell could be found in these bone marrow cavities at this time. Some cell condensations at the origin of connective tissue trabeculae could be seen in the vicinity of the implant, some of which were synthesizing an ECM (extracellular matrix) undergoing mineralization. Resorption marks were apparent at the implant surface into which the tissue had grown. SEM showed that the material was constituted of small white particles disseminated within a grey matrix with some micropores. Several grey-levels were visible in the matrix suggesting an unhomogeneous setting.

The control bone defect was filled with a loose connective tissue in the form of a network with connective tissue trabeculae several tens of $\mu \mathrm{m}$ in thickness. Ossification had begun at the edges of the defect.

-After six weeks: the implants showed a mineral core which still appeared as a solid. The external cylinder region was invaded by bone trabeculae. The bone marrow cavities between the trabeculae were completely filled with implant fragments. These fragments embedded within the bone tissue contained cells between the crystals. The bone trabeculae structure was immature with many 
remodelling marks. An organic matrix was visible in some sites at the implant surface and had invaded the space available between the material grains. Many grains detached from the material were phagocytosed by macrophages and giant cells.

SEM revealed the presence of material fragments far from the implantation zone in the condyle. A dissolution zone 100 to $300 \mu \mathrm{m}$ thick under the material surface could be observed in one implant. Mineralizing bone trabeculae were ingrowing in this zone. The material core lined by this dissolution zone was edged by a densified layer less than $100 \mu \mathrm{m}$ thick.

The control defects were occupied by low density trabecular bone in which the bone marrow cavities contained cytologically normal marrow.

-After eighteen weeks: small grains emitted by the material were less numerous in the bone marrow cavities surrounding the fragmented materials. The remaining implants were fragmented with two or three big fragments totally lined by bone trabeculae parallel to the fragment surfaces. This lining bone layer was linked to the cortical bone by bone trabeculae.

The SEM showed that the material was a solid with pores ranging from a few to one hundred $\mu \mathrm{m}$. White grains of different sizes ranging from one or two to several tens of $\mu \mathrm{m}$ were dispersed within a grey matrix. Bone matrix showing different grey levels was in contact with the material. Some white particles could be found in the Havers canals and were probably grouped within the histiocytes. Some such particles were included within the bone matrix.

The control zones were difficult to differentiate from the rest of the bone tissue. However, the low density of trabeculae in this region was characteristic of the control zone.

Figure 1: Back-scattered SEM of a two weeks implanted cement ( C). Very immature bone trabeculae $(\rightarrow)$ and bone fragments are in contact with the implant surface. The implant shows different grey levels due to different densities suggesting that the cement did not set homogeneously after implantation. Some implant fragments are detached from the surface. Bar : $1 \mathrm{~mm}$.

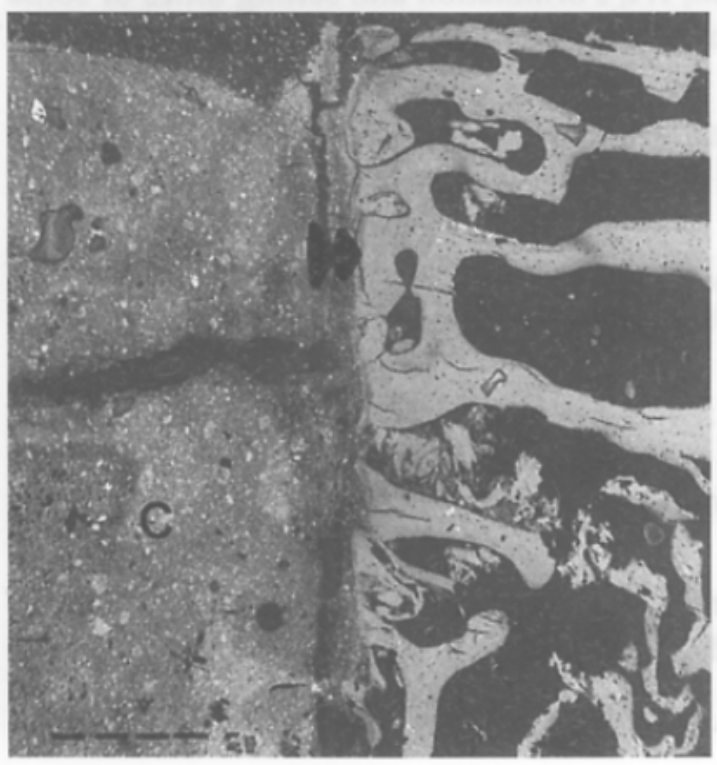

Figure 2: Interface of a six week implanted cement (IC) with bone tissue (BT) with osteocytes (os) at the cement contact. The cement contains two phases. The white particles are made of TCP. Bar: $10 \mu \mathrm{m}$.

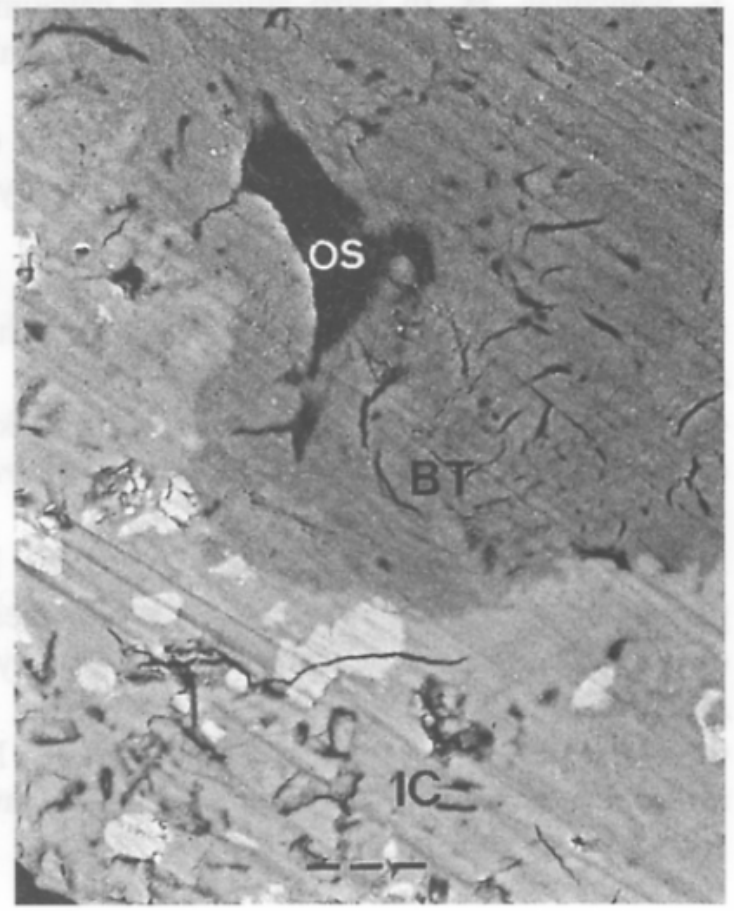




\section{DISCUSSION AND CONCLUSION}

This study showed that $: 1$ / The cement set when injected into a bone marrow cavity and formed a porous calcium phosphate structure; $2 /$ Two different calcium phosphate phases with different solubility rates could be identified by SEM observation.; 3/ A mild foreign body reaction occurred in the vicinity of the material with a majority of mononucleated cells. Calcium phosphate particles were phagocytosed in these cells ; 4/ The degradation rate of the material was relatively high when compared to the usual HA and TCP ceramics but compatible with the ingrowth of bone formingtrabeculae within the resorbing material.

Different fast-setting calcium phosphates have been described that all show osteoconductive properties and can be injected $(2,3,4,5)$. In this experiment, the dissolution products induced a low foreign body reaction. However, the presence of macrophages and giant cells in the implantation site did not impair bone formation within the same site. Some differentiating osteoblasts synthesizing an osteoid matrix were identified among the macrophages. No increase in the bone resorption could be detected at any time.

The ossification process occurring at the material contact was not exactly identical to that occurring at the contact of calcium phosphate ceramics (6). It is frequent that an organic matrix deposit is found at the material surface ingrowing between the crystallites of the mineral matrix. This matrix is not lined by osteoblasts like osteoid and does not precede the formation of bone at the material surface like it is at the ceramic surface. On the opposite, this matrix could follow the formation of bone in the close proximity to the mineral. Osteoblasts are not, or only very rarely, found at the material surface as is observed at the surface of calcium phosphate ceramics. Most of the osteoblasts differentiate at some distance from the material and there is a neat ingrowth of the forming bone trabeculae from the cavity edges into the spaces made available by the material resorption. There is no material degradation resulting from a creeping substitution process as has been shown at the ceramic contact.

\section{REFERENCES}

1- Nancollas, H, In vitro studies of calcium phosphate crystallisation. In : Mann, S, Webb, J, Williams, RJP, (eds) Biomineralization. Chemical and Biochemical Perspectives. VCH New York, 1989 , pp157-182

2- Driessens, FCM, Boltong, MG, Bermudez, O, Planell, JA, Formulation and setting times of some calcium orthophosphate cements: a pilot study. Journal of Material Science: Material in Medicine $1993 ; 4: 503-508$

3- Driessens, FCM, Boltong, MG, Bermudez, O, Planell, JA, Ginebra, MP, Fernandez, E, Effective formulations for the preparation of calcium phosphate bone cements. Journal of Material Science: Material in Medicine 1994 ; 5 : 164-170

4- Ishikawa, K, Takagi, S, Chow, LC, Ishikawa, Y, Properties and mechanisms of fast-setting calcium phosphate cements. Journal of Material Science: Material in Medicine 1996 ; 17 : 14291432

5- Kurashina, K, Kurita, H, Hirano, M, de Blieck, JMA, Klein, CPAT, de Groot, K, Calcium phosphate cement: in vitro and in vivo studies of the $\alpha$-tricalcium phosphate-dicalcium phosphate dibasic-tetracalcium phosphate monoxide system. Journal of Material Science: Material in Medicine 1995 ; 6 : 343-347

6- Frayssinet, P, Trouillet, J, Rouquet, N, Azimus, E, Autefage, A, Osseointegration of macroporous calcium phosphate ceramics having a different chemical composition Biomaterials $1993 ; 14: 423-429$ 